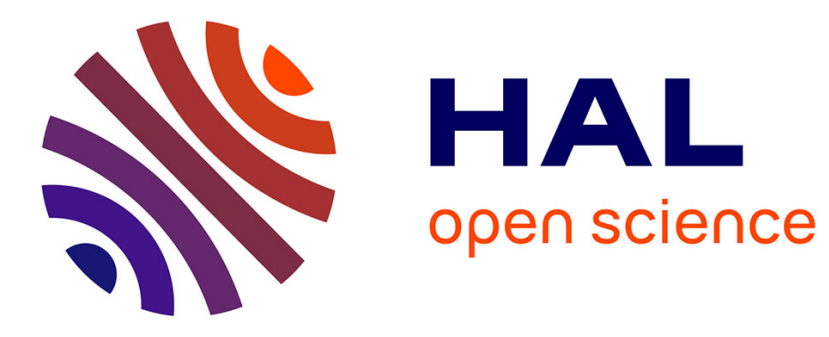

\title{
Inflammatory dendritic cells in mice and humans.
}

Elodie Segura, Sebastian Amigorena

\section{To cite this version:}

Elodie Segura, Sebastian Amigorena. Inflammatory dendritic cells in mice and humans.. Trends in Immunology, 2013, 34 (9), pp.440-5. 10.1016/j.it.2013.06.001 . inserm-00846095

\section{HAL Id: inserm-00846095 https://www.hal.inserm.fr/inserm-00846095}

Submitted on 18 Jul 2013

HAL is a multi-disciplinary open access archive for the deposit and dissemination of scientific research documents, whether they are published or not. The documents may come from teaching and research institutions in France or abroad, or from public or private research centers.
L'archive ouverte pluridisciplinaire HAL, est destinée au dépôt et à la diffusion de documents scientifiques de niveau recherche, publiés ou non, émanant des établissements d'enseignement et de recherche français ou étrangers, des laboratoires publics ou privés. 


\section{A - Steady State}
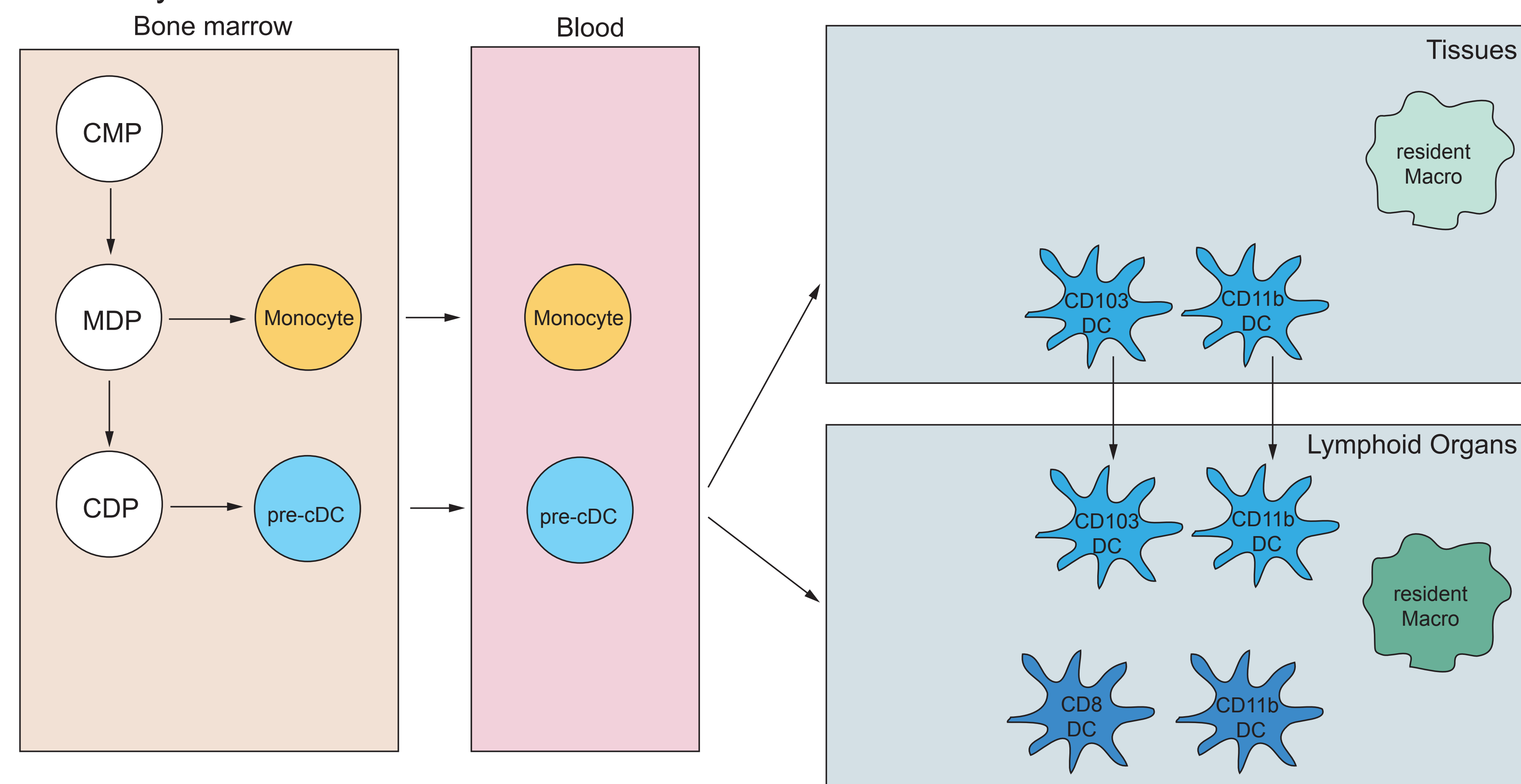

\section{B - Inflammation}

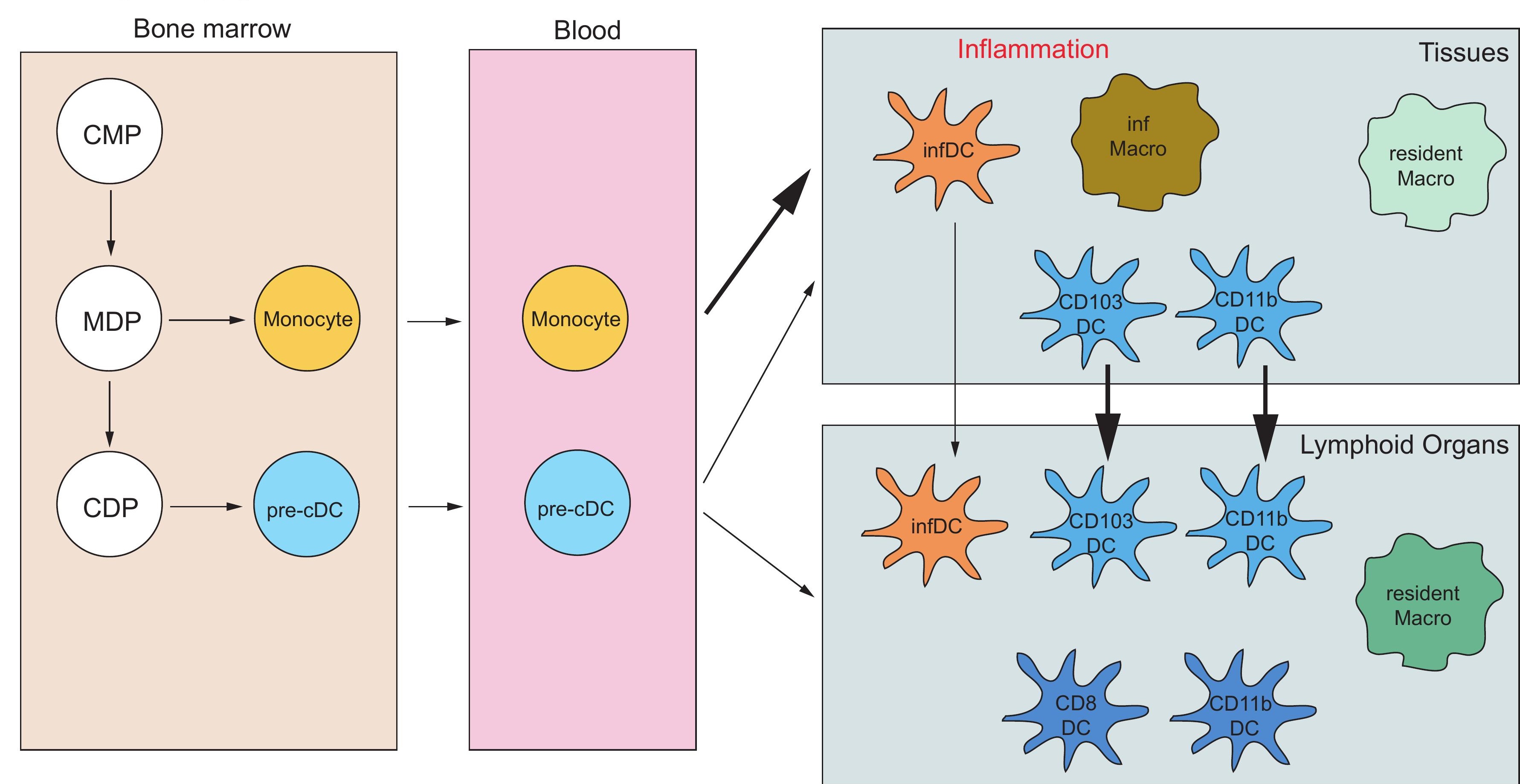

